\title{
Relationship of serum elastin peptide level to single breath transfer factor for carbon monoxide in French coal miners
}

Catherine Frette, Marie-Paule Jacob, Shao Ming Wei, Jean-Pierre Bertrand, Philippe Laurent, Francine Kauffmann, Quang Thieu Pham
Institut National de la Santé et de la Recherche Médicale (INSERM) Unité 169, Villejuif, France

C Frette

F Kauffmann

INSERM U460, Paris France

M P Jacob

Department of Pathophysiology, Shanghai Second

Medical University,

Shanghai, China

$S M$ Wei

Lorraine Basin Coal

Mines Medical

Service, Freyming

Merlebach, France

J P Bertrand

Department of

Pneumology, Pau

Hospital, Pau, France

P Laurent

INSERM U420, Nancy,

France

Q T Pham

Correspondence to:

Dr F Kauffmann,

Epidemiological Research

Unit, INSERM U169,

16 Avenue P V Couturier,

94807 Villejuif cedex,

France.

Received 4 July 1997

Returned to authors

25 July 1997

Revised version received

14 August 1997

Accepted for publication

4 September 1997

\begin{abstract}
Background - Clinical and epidemiological studies have given discordant results on the usefulness of the level of circulating elastin peptide (EP), a potential marker of both elastin destruction (a key phenomenon in pulmonary emphysema) and neosynthesis, for assessing structural changes in the lung extracellular matrix. The aim of the present study was to explore the relationship between levels of EP and forced expiratory volume in one second $\left(F E V_{1}\right)$ and single breath transfer factor for carbon monoxide (TLCO and KCO) in coal miners.
\end{abstract}

Methods - The study population comprised 227 working coal miners aged 34-50 years consisting of 75 miners heavily exposed to underground coal dust with pulmonary radiographs classified as $0 / 1$ or $1 / 0$ by the International Labour Office classification, 75 exposed miners with radiographs classified as normal (0/0), and 77 miners slightly exposed to coal dust with normal radiographs. The subjects answered a standardised questionnaire and performed spirometric tests and a carbon monoxide (CO) transfer test.

Results - No association was observed between EP levels and \% predicted $\mathrm{FEV}_{1}$ (or $\mathrm{FEV}_{1}$ /FVC). The level of EP increased significantly with decreased $\%$ predicted TLCO $(r=-0.20)$. Miners in the lowest \% predicted KCO quintile had higher EP levels than the rest $(3.28$ (1.37) vs 2.47 (1.16)). A significantly lower EP level was observed in miners with radiographs classified as $1 / 0$ or $0 / 1$, especially in those with round opacities, compared with miners with a normal radiograph, and in current smokers compared with the rest.

Conclusions - The results of this study suggest that the level of EP may reflect some remodelling activity in emphysema and lung fibrosis.

(Thorax 1997;52:1045-1050)

Keywords: elastin peptide, carbon monoxide lung transfer factor (TLCO), carbon monoxide transfer coefficient (KCO), epidemiology.

Structural alterations of lung extracellular matrix are likely to play a major part in various diseases of the lung including pulmonary emphysema and pulmonary fibrosis. Biochemically, current concepts suggest that changes in elastin fibres resulting from both degradation and neosynthesis are involved in the pathogenesis of pulmonary emphysema, whereas alterations of collagens, including an imbalance of fibrolysis and fibrogenesis in favour of fibrogenesis, cause pulmonary fibrosis. Several peripheral biological markers have been proposed to estimate the turnover of lung elastin. Elastin peptide (EP) levels have been suggested as a potential marker of lung elastin degradation $^{1}$ to detect early emphysema and susceptible smokers. ${ }^{2}$ Clinical studies have shown that the level of EP was higher in patients with chronic obstructive pulmonary disease than in healthy subjects ${ }^{1-5}$ and higher in smokers than in non-smokers. ${ }^{14}$ However, in an epidemiological survey conducted among middle aged policemen we did not observe any relation between EP levels and either smoking habits or forced expiratory volume in one second $\left(\mathrm{FEV}_{1}\right),{ }^{6}$ and we failed to observe an increase in EP levels in patients with established emphysema, assessed by CT scanning. ${ }^{7}$ To date no epidemiological study has included both EP levels and a functional test more specific for emphysema than $\mathrm{FEV}_{1}$ such as carbon monoxide lung transfer factor (TLCO).

An epidemiological study was therefore conducted among coal miners to determine whether or not increased levels of EP relate to decreased $\mathrm{FEV}_{1}$ and to decreased single breath carbon monoxide transfer factor (TLCO and KCO).

\section{Methods}

The selection of the subjects has been described in detail elsewhere. ${ }^{89}$ The population examined in 1990/91 consisted of 240 working coal miners aged $34-50$ years, including 80 subjects heavily exposed to underground coal dust (at least 10 years at coal face with 19 years on average) with pulmonary radiographs classified by four independent physicians as $0 / 1$ or $1 / 0$ according to the International Labour Organisation classification of pneumoconioses, 80 subjects exposed to underground coal dust with normal radiographs, and 80 subjects slightly exposed (four years on average at coal face) with normal radiographs. ${ }^{810}$ No miner had established pneumoconiosis. The three groups were matched for age, height, weight, and smoking habits (table 1) with regard to smoking status (non-smoker, ex-smoker, current smoker) and pack-years $(<9,10-19, \geq 20)$. No miner had an emphysema score assessed by 
Table 1 Descriptive characteristics of the 227 coal miners according to the inclusion criteria

\begin{tabular}{|c|c|c|c|}
\hline & $\begin{array}{l}\text { Radiograph } 0 / 1 \text { or } 1 / 0 \\
\text { heavily exposed }\end{array}$ & $\begin{array}{l}\text { Radiograph } 0 / 0 \\
\text { heavily exposed }\end{array}$ & $\begin{array}{l}\text { Radiograph } 0 / 0 \\
\text { no/minor exposure }\end{array}$ \\
\hline No. of subjects & 75 & 75 & 77 \\
\hline Mean (SD) age (years) & $42.7(3.4)$ & $42.9(3.5)$ & $42.1(3.7)$ \\
\hline Mean (SD) height $(\mathrm{cm})$ & $174.9(6.0)$ & $174.2(5.9)$ & $173.6(6.3)$ \\
\hline \multicolumn{4}{|l|}{ Smoking habits* } \\
\hline Never smokers & 23.0 & 23.6 & 20.8 \\
\hline Ex-smokers & 27.0 & 23.6 & 20.8 \\
\hline Smokers & 50.0 & 52.8 & 58.4 \\
\hline \multicolumn{4}{|l|}{ Mean (SD) pack-years } \\
\hline Ex-smokers & $17.1(9.7)$ & $18.0(9.3)$ & $20.7(9.2)$ \\
\hline Smokers & $12.3(8.5)$ & $12.2(9.5)$ & $12.4(9.8)$ \\
\hline \multicolumn{4}{|l|}{ Radiographic data } \\
\hline \multicolumn{4}{|l|}{ Profusion } \\
\hline $0 / 1$ & 69.3 & - & - \\
\hline $1 / 0$ & 30.7 & - & - \\
\hline \multicolumn{4}{|c|}{ Shape of small opacities $\dagger$} \\
\hline Regular $(\mathrm{p} / \mathrm{q})$ & 62.9 & - & - \\
\hline Irregular $(\mathrm{s} / \mathrm{t})$ & 37.1 & - & - \\
\hline
\end{tabular}

* Four with missing data.

† Five with missing data.

The three groups were matched for age, height, and smoking habits.

high resolution CT scanning of more than $5 \% .^{7}$ All subjects gave written informed consent.

Subjects were interviewed with the European Coal and Steel Community questionnaire and classified as never smokers, ex-smokers (of at least one year's duration), and current smokers. $\mathrm{FEV}_{1}$ and forced vital capacity (FVC) were measured on a spirometer (Spiromatic Electronic Spirometer, Fleish 3 pneumotachograph, Metabo SA, Epalinges, Switzerland). Single breath transfer factor for carbon monoxide ( $\mathrm{TLCO}$ in $\mathrm{ml} / \mathrm{min} / \mathrm{mm} \mathrm{Hg}$ ) was determined using a Jaeger Alveotest apparatus with two determinations five minutes apart. Alveolar volume was derived from the single breath dilution of inspired helium for the computation of the transfer coefficient $(\mathrm{KCO}=$ TLCO/VA, in $\mathrm{ml} / \mathrm{min} / \mathrm{mm} \mathrm{Hg} / \mathrm{l}$ ), the alveolar volume adjusted TLCO. TLCO and KCO values were taken as the mean of two determinations. The results were unchanged when haemoglobin was taken into account and are not presented here. Total lung capacity (TLC) was measured with an Isovolume plethysmograph (Master Lab Body Jaeger) and the values used were the means of two determinations. Percentage predicted values for $\mathrm{FEV}_{1}$, TLCO and Kco were based on the reference values of Quanjer et al. ${ }^{11}$

Blood samples were taken and the serum was frozen and kept at $-80^{\circ} \mathrm{C}$ until measurements of elastin peptide were carried out. Blood samples were available from 227 subjects. The serum EP level was measured using a competitive enzyme linked immunosorbent assay (ELISA) with polyclonal antibodies by the same technician (SMW) with the same immune serum and the same methods as in our previous studies. ${ }^{6712}$ The elastin peptides used for obtaining antibodies and as reference in the assay were prepared from human aorta elastin hydrolysed with $1 \mathrm{M} \mathrm{KOH}$ in $80 \%$ aqueous ethanol (kappa-elastin). Complete or near complete cross reactivity has been shown previously between our chemically produced kappa-elastin and four elastase produced elastin peptides (P33\%, P95\%, L25\%, L85\%) with the antibodies raised against kappaelastin. ${ }^{12}$ Serum elastin peptide determinations were run in triplicate and the results expressed as $\mu$ g kappa-elastin equivalents per $\mathrm{ml}$ serum. The assay was shown to be sensitive from 0.3 to $22 \mu \mathrm{g} / \mathrm{ml}$ of serum ${ }^{13}$ and to give reproducible results (interbatch coefficient of variation from day to day measurement of elastin peptide level in human serum using the same immune serum and kappa-elastin of $8.5 \%$ ).

The relationships between EP levels and smoking, radiographic appearance, and lung function were considered first by univariate analysis and then by multivariate analysis. Relationships were explored by analysis of variance, multiple linear regression, and correlation. ${ }^{14}$ The SAS statistical software package (SAS Institute Inc, Cary, North Carolina, USA) was used for all analyses. Results are given as mean (SD) values unless stated otherwise.

\section{Results}

The distribution of EP levels followed a Gaussian curve (mean (SD) $2.59(1.20) \mu \mathrm{g} / \mathrm{ml}$, range $0.36-7.08 \mu \mathrm{g} / \mathrm{ml}$ ) with one outlier of $10.27 \mu \mathrm{g} /$ $\mathrm{ml}$. No difference was observed between the subjects studied and those in whom the EP level was not determined $(n=13)$ concerning age, smoking habits, dust exposure, and radiographic appearance. Subjects in whom the EP level was not determined had lower $(\mathrm{p}=0.03)$ $\%$ predicted $\mathrm{FEV}_{1}$ than the others. There was no difference in EP levels between the sample studied and those in whom TLCO or KCO were not measured $(n=33)$. The descriptive characteristics of the subjects are shown in tables 1 and 2. The mean age of the subjects was 43 years (range 34-50) and more than half were current smokers. All but one of the ex-smokers had stopped for at least five years.

\section{RELATIONSHIP BETWEEN EP LEVELS AND} SMOKING

As expected, $\mathrm{FEV}_{1}$ decreased with smoking (\% predicted $\mathrm{FEV}_{1}$ 1.08, 1.01, and 1.02 in nonsmokers, ex-smokers, and current smokers, respectively; $\mathrm{p} \leq 0.01)$. There was no relation between age and EP level (regression coefficient 0.001 (95\% confidence interval (CI) -0.043 to 0.041)). The lowest mean EP level was 
Table 2 Lung function and mean (SD) elastin peptide levels in the whole sample

\begin{tabular}{lc}
\hline $\mathrm{FEV}_{1}(\mathrm{l})$ & $3.89(0.57)$ \\
$\mathrm{FEV}_{1} / \mathrm{FVC}$ & $0.81(0.05)$ \\
$\mathrm{TLCO}_{(\mathrm{ml} / \mathrm{min} / \mathrm{mm} \mathrm{Hg})^{*}}$ & $33.7(9.8)$ \\
$\mathrm{KCO}(\mathrm{ml} / \mathrm{min} / \mathrm{mm} \mathrm{Hg} / \mathrm{l})^{*}$ & $5.1(1.1)$ \\
$\mathrm{TLC}(1)$ & $6.4(1.1)$ \\
$\mathrm{Hb}(\mathrm{g} / \mathrm{dl})$ & $14.9(0.9)$ \\
$\mathrm{FEV}_{1}(\%$ predicted$)$ & $1.03(0.13)$ \\
TLCO (\% predicted) & $1.08(0.32)$ \\
KCO $(\%$ predicted) & $0.87(0.20)$ \\
Elastin peptide level $(\mu \mathrm{g} / \mathrm{ml})$ & $2.59(1.20)$
\end{tabular}

$\mathrm{FEV}_{1}=$ forced expiratory volume in one second; $\mathrm{FVC}=$ forced vital capacity; TLCO = carbon monoxide lung transfer factor; $\mathrm{KCO}=$ carbon monoxide transfer coefficient; TLC = total lung capacity; $\mathrm{Hb}=$ haemoglobin.

*apacity; $\mathrm{Hb}=$ haemoglobin. to SI units is obtained by multiplying the figures presented by to SI unit.

observed in the 120 smokers $(2.45(1.08) \mu \mathrm{g} /$ $\mathrm{ml})$, and similar EP levels were found in the 53 ex-smokers $(2.77(1.12) \mu \mathrm{g} / \mathrm{ml})$ and the 30 non-smokers $(2.68(1.49) \mu \mathrm{g} / \mathrm{ml})$. The relation between smoking habits and EP level was not significant $(p=0.21)$. When non-smokers and ex-smokers were combined and compared with current smokers the relation of current smoking to EP level was of borderline significance $(2.45$ (1.08) versus $2.73(1.30) \mu \mathrm{g} / \mathrm{ml} ; \mathrm{p}=0.08)$. The current smokers who did not report smoking on the day of examination $(n=16)$ had similar EP levels to the non-smokers or ex-smokers (2.74 (1.30) versus $2.73(1.30) \mu \mathrm{g} / \mathrm{ml}$, respectively). The relation of smoking on the day of examination to EP level was significant $(2.75$ (1.29) versus $2.44(1.03) \mu \mathrm{g} / \mathrm{ml} ; \mathrm{p}=0.05)$ for those who did not and did smoke on that day, respectively). The EP level was unrelated to pack-years, both in ex-smokers and current smokers, and unrelated to the length of time since giving up smoking.

RELATIONSHIP BETWEEN EP LEVELS AND RADIOGRAPHIC APPEARANCE

The EP levels were significantly lower $(\mathrm{p} \leq 0.001)$ in coal miners with radiographic classification $0 / 1(2.27(0.98) \mu \mathrm{g} / \mathrm{ml})$ or $1 / 0$ $(2.14(0.72) \mu \mathrm{g} / \mathrm{ml})$ than in miners with normal radiographs $(2.76(1.28) \mu \mathrm{g} / \mathrm{ml})$. Miners with a predominant round shape of small opacities (p, q) had lower EP levels (2.09 (0.95) $\mu \mathrm{g} / \mathrm{ml})$ than those with irregular $(\mathrm{s}, \mathrm{t})$ opacities $(2.51$ $(0.81) \mu \mathrm{g} / \mathrm{ml} ; \mathrm{p}=0.06)$. The decrease in EP level in subjects with radiographs classified as $1 / 0$ or $0 / 1$ was clearly observed in both current smokers and the ex-smokers and non-smokers combined $(2.00(0.93)$ versus $2.65(1.09) \mu \mathrm{g} /$ $\mathrm{ml}$ and $2.42(0.83)$ versus $2.90(1.49) \mu \mathrm{g} / \mathrm{ml}$, respectively) and remained significant after adjustment for smoking $(\mathrm{p} \leq 0.001)$. Similar results were obtained if smoking on the day of the examination rather than current smoking was studied. After adjusting for radiographic classification the decreases in EP level observed among current smokers compared with the others or among smokers on the day of examination compared with the others were significant $(p<0.05)$. Miners heavily exposed to coal dust did not have a different EP level from non-exposed miners or those moderately exposed to coal dust in either the whole sample

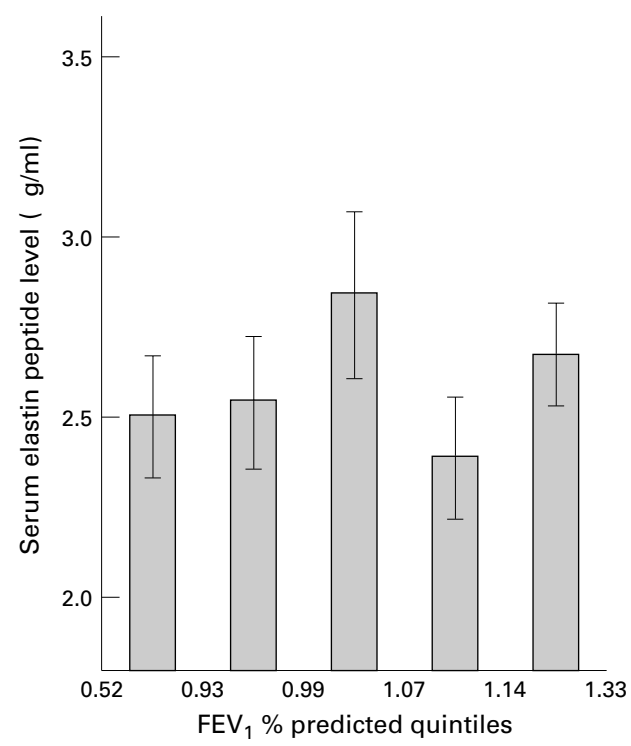

Figure 1 Serum elastin peptide level according to forced expiratory volume in one second $(F E V, \%$ predicted quintiles $(n=227) ; A N O V A, p=0.45$. Correlation coefficient (based on continuous $F E V_{1} \%$ predicted) $=$ $0.06, p=0.40$.

or when the analysis was restricted to those with normal radiographs (in miners with normal radiographs EP levels of $2.84(1.47) \mu \mathrm{g} / \mathrm{ml}$ were found in heavily exposed miners compared with $2.69(1.08) \mu \mathrm{g} / \mathrm{ml}$ in the other groups).

RELATIONSHIP BETWEEN EP LEVELS AND

PULMONARY FUNCTION

No relation was observed between EP level and $\mathrm{FEV}_{1}$ quintiles (fig 1). The regression coefficient of EP level on \% predicted $\mathrm{FEV}_{1}$ was 0.51 (95\% CI -0.67 to 1.69$)$. The EP level was also not related to the $\mathrm{FEV}_{1} / \mathrm{FVC}$ ratio.

The EP level significantly increased with decreased \% predicted TLCO (regression coefficient $-0.79(95 \% \mathrm{CI}-1.32$ to -0.26$) ; \mathrm{p}=$ 0.004). The increase in EP level with decreased TLCO was continuous as shown by the relation of EP level with \% predicted TLCO quintiles (fig 2), with EP levels ranging from 3.10 (1.55) to $2.32(0.71) \mu \mathrm{g} / \mathrm{ml} \quad(\mathrm{p}=0.05)$. TLCO decreased significantly with smoking habits $(1.03$ (0.32) versus $1.15(0.33) \mu \mathrm{g} / \mathrm{ml}$ in current smokers and non-smokers and ex-smokers combined, respectively; $\mathrm{p}=0.01)$. TLCO $\%$ predicted was unexpectedly higher among men with radiographs classified as $1 / 0$ or $0 / 1$ than among miners with normal radiographs (1.16 (0.26) versus $1.05(0.34) \mu \mathrm{g} / \mathrm{ml}$, respectively; $\mathrm{p}=0.02)$. The association observed between EP level and \% predicted TLCo persisted when only the 138 subjects with normal radiographs (regression coefficient -0.63 (95\% CI -1.42 to -0.16$) ; \mathrm{p}=0.02)$.

The EP level increased significantly with decreased \% predicted Kco quintiles (fig 3). The correlation between the EP level and Kco was significant (regression coefficient -1.48 $(95 \%$ CI -2.35 to -0.61$) ; p=0.001)$. Subjects in the lowest \% predicted Kco quintile had a clearly higher EP level than the other 


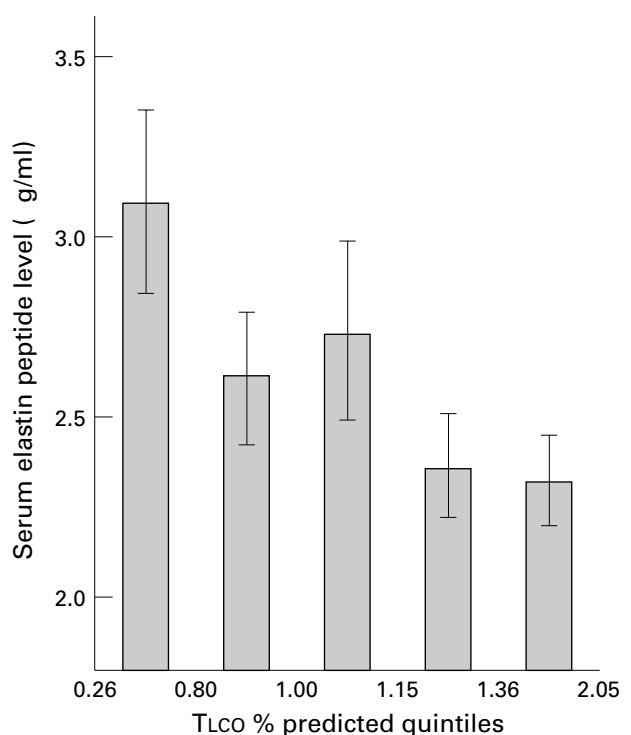

Figure 2 Serum elastin peptide level according to carbon monoxide lung transfer factor (TLCO) \% predicted quintiles ( $n=194) ;$ ANOVA, $p=0.05$; $t$ test (1st quintile versus others), $p=0.01$. Correlation coefficient (based on continuous TLCO \% predicted) $=-0.20, p=0.01$

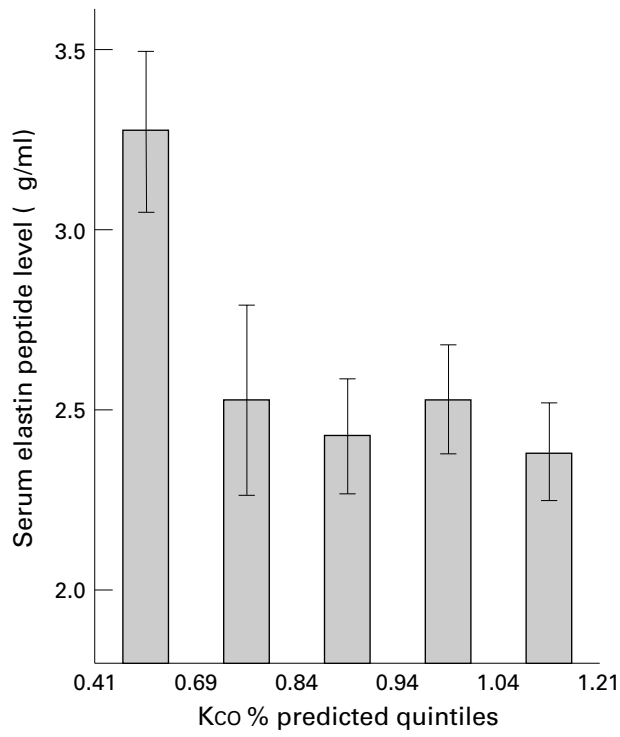

Figure 3 Serum elastin peptide level according to carbon monoxide transfer coefficient (KCO) \% predicted quintiles $(n=194) ; A N O V A, p=0.009 ; t$ test (1st quintile versus others), $p=0.0003$. Correlation coefficient (based on continuous KCO \% predicted) $=-0.24, p=0.001$.

groups (3.28 (1.37) $\mu \mathrm{g} / \mathrm{ml}$ versus 2.47 $(1.16) \mu \mathrm{g} / \mathrm{ml}$, respectively; $\mathrm{p} \leq 0.001)$. However, the relationship between Kco quintiles and the EP level was not significantly different from a linear relationship. Kco \% predicted decreased with smoking habits in current smokers and the other groups $(0.84(0.19) \mu \mathrm{g} /$ $\mathrm{ml}$ versus $0.91(0.20) \mu \mathrm{g} / \mathrm{ml}$, respectively; $\mathrm{p}=$ $0.02)$. Kco was also higher in those with radiographs classified as $1 / 0$ or $0 / 1$ than in those with normal radiographs $(0.93(0.15) \mu \mathrm{g} / \mathrm{ml}$ versus $0.85(0.21) \mu \mathrm{g} / \mathrm{ml} ; \mathrm{p}=0.01)$. The correlation of EP level to \% predicted Kco was similar when only the miners with normal radiographs were considered (regression coefficient $-1.54(95 \%$ CI -2.58 to -0.52$)$; $\mathrm{p}=0.004)$.

To control both for radiographic classification and smoking, multiple linear regressions of \% predicted $\mathrm{FEV}_{1}$, TLCO, and KcO on EP levels were then performed. The inverse relations of EP level to TLCO and KCO (table 3) persisted after adjustment for radiographic classification and smoking.

\section{Discussion}

In this population of coal miners the EP levels were significantly higher in those with the lowest TLCO and KCO (the alveolar volume adjusted TLCO) values, whereas no association was observed between EP level and $\mathrm{FEV}_{1}$ (or $\mathrm{FEV}_{1} / \mathrm{FVC}$ ). A significantly lower EP level was observed both in miners with radiographs classified as $1 / 0$ or $0 / 1$ compared with miners with normal radiographs, and in current smokers compared with non-smokers and ex-smokers.

Comparison of the results from clinical studies $^{131315}$ is limited by the lack of standardisation in the measurement of EP levels. This has led to the identification of various elastin peptides and then to heterogeneity in the EP levels reported which differ by a factor as high as $1000 .^{1313} \mathrm{EP}$ levels should be regarded only as relative and not absolute. ${ }^{12}$ The fact that the same method was applied by the same technician using the same antibodies in the various studies we conducted ${ }^{67}$ allows us to compare EP levels in our populations.

The relation of the level of EP to functional tests is poorly documented with very few clinical studies on highly selected subjects. No association was observed between $\mathrm{FEV}_{1}$ and EP level among coal miners, which agrees with our previous epidemiological observations in policemen, ${ }^{6}$ nor was there any relation between $\mathrm{EP}$ levels and $\mathrm{FEV}_{1}$ or $\mathrm{FEV}_{1} / \mathrm{FVC}$ in three clinical studies. ${ }^{1215}$ Other reports have described an inverse relation between EP levels and $\mathrm{FEV}_{1}$ in a sample of 44 patients with chronic obstructive lung disease ${ }^{16}$ and $\mathrm{FEV}_{1} /$ FVC in 28 subjects. ${ }^{4}$ Independent of age and smoking habits, the EP level increased as TLCO and KCO decreased in all miners as well as in those with normal radiographs. Associations between the EP level and TLCO and Kco have not previously been observed but have only been studied in a sample of 17 subjects without interstitial disease ${ }^{15}$ and in 44 patients with chronic obstructive lung disease. ${ }^{16}$

$\mathrm{FEV}_{1}$ is not a specific test for emphysema. TLCO assesses the integrity of the alveolarcapillary surface area and capillary blood volume and has been proposed as a more specific functional test for emphysema than $\mathrm{FEV}_{1} \cdot{ }^{1718}$ However, TLco also clearly relates to other pulmonary abnormalities such as fibrosis. There was no subject in this population with recognised pneumoconiosis and the level of TLC suggests that no miner, even those with radiographs classified as $0 / 1$ or $1 / 0$, had established pulmonary fibrosis. As no subject had more than 5\% CT scan emphysema score, ${ }^{7}$ emphysematous lesions cannot be considered 
Table 3 Factors related to serum elastin peptide level $(\mu \mathrm{g} / \mathrm{ml})$. Multiple linear regression models with $\%$ predicted FEV TLCO and KCO

\begin{tabular}{llll}
\hline & $\begin{array}{l}\text { Model with } \\
F E V_{1} \% \text { predicted }\end{array}$ & $\begin{array}{l}\text { Model with } \\
\text { TLCO \% predicted }\end{array}$ & $\begin{array}{l}\text { Model with } \\
\text { KCo \% predicted }\end{array}$ \\
\hline Radiograph $1 / 0$ or $0 / 1$ & -0.55 & -0.52 & -0.49 \\
versus $0 / 0$ & $(-0.87$ to -0.22$)$ & $(-0.90$ to -0.14$)$ & $\begin{array}{l}(-0.87 \text { to }-0.12) \\
\mathrm{p}=0.01\end{array}$ \\
Current smoking on the day & $\mathrm{p}=0.001$ & -0.008 & -0.58 \\
of examination versus other & -0.36 & $(-0.86$ to -0.17$)$ & $\begin{array}{l}(-0.93 \text { to }-0.24) \\
\mathrm{p}=0.001\end{array}$ \\
Lung function parameter & $\mathrm{p}=0.06$ to -0.05$)$ & $\mathrm{p}=0.004$ & -1.53 \\
& 0.22 & $(-0.72$ & $(-2.44$ to -0.63$)$ \\
& $(-0.95$ to 1.39$)$ & $\mathrm{p}=0.01$ & $\mathrm{p}=0.001$ \\
\hline
\end{tabular}

$\mathrm{FEV}_{1}=$ forced expiratory volume in one second; TLCO = carbon monoxide lung transfer factor; KCO=carbon monoxide transfer coefficient.

Values are regression coefficients with $95 \%$ confidence intervals.

as severe. It is likely that the higher EP levels in miners with low TLCO (and KCO) relates to early stages of lung elastin destruction. However, it may be that the lowest EP levels in those with the highest TLCO or Kco reflect decreased elastin neosynthesis. Conflicting results have been observed between EP levels and severe emphysema assessed by CT scanning. ${ }^{57}$ Whereas CT scanning is an excellent diagnostic method for established emphysema, its usefulness in the early stages of the disease has been debated ${ }^{19}$ and results suggest that mild and moderate emphysema may be missed. ${ }^{20}$ The lack of a relationship between the emphysema score on the CT scan and EP levels in established emphysema as previously observed ${ }^{7}$ may reflect the lack of association of EP levels with the severity of the disease. The relationship between increased EP levels and KCO may correspond to emphysematous lesions not yet detectable by CT scanning. The beginning of the emphysematous process might be better evaluated by biological markers such as desmosine ${ }^{21-23}$ or EP levels than by CT scanning. Follow up studies are necessary to delineate the activity and the severity of the destruction process.

Interpretation of changes in EP levels is complicated by the fact that they result both from elastin degradation and neosynthesis. It is in this context that we previously interpreted a decrease in EP levels with age as potentially a result of decreased neosynthesis due to aging. ${ }^{6}$ Such a decrease in EP levels with age was not observed in the present survey but the limited age range of our sample of miners did not allow the relation between age and EP level to be completely explored. The lower EP levels in current smokers compared with non-smokers and ex-smokers, and particularly in those who smoked on the day of the examination, fits with the hypothesis of decreased elastin neosynthesis due to smoking. The difference in EP levels in current smokers compared with smokers who did not smoke on the day of the examination, ex-smokers, and non-smokers supports the hypothesis that the effect of smoking on levels of EP may be exclusively acute. The hypothesis of acute processes has already been put forward to interpret the lack of difference in urine levels of desmosine (a marker of elastin degradation) between normal subjects and emphysematous patients and the large day to day variation of urinary desmosine levels. ${ }^{24}$ In clinical studies carried out in highly selected samples both an increase in EP levels with smoking ${ }^{1}$ and no relation $^{23}$ have been reported. In these studies no information was provided regarding smoking on the day of examination. Further studies including sensitive assays of desmosine $e^{23}$ are needed to understand acute and chronic events related to elastin degradation and neosynthesis.

The decreased level of EP in miners with radiographs classified as $0 / 1$ or $1 / 0$ compared with those with normal radiographs may reflect the relationships of the various elements of the extracellular matrix. The EP level was particularly low in those with small round opacities, which are those more typical of coal workers' pneumoconiosis. ${ }^{25}$ Collagen and elastin fibres are mechanically interconnected with each other ${ }^{26}$ and collagen fibres may constitute a network for deposition of elastin fibres. ${ }^{27}$ Opacities may result in inefficient remodelling. Experimental studies have shown that interstitial collagenase may initiate the development of emphysema. ${ }^{28}$ Enlargement of alveolar walls with fibrous tissue was noted in emphysematous patients. ${ }^{29}$ Furthermore, recent results based on biological markers have shown an increase in both elastin and collagen degradation in patients with COPD and in smokers compared with non-smokers. ${ }^{23}$ Emphysema may result from fibrosis in coal miners ${ }^{30}$ and, conversely, emphysema may be followed by pulmonary fibrosis. ${ }^{31}$ To date no study has looked at EP levels in relation to severe or mild fibrosis. Remodelling of the various elements of the extracellular matrix may occur with smoking and in the earliest stages of fibrosis assessed here by radiographs classified as $0 / 1$ or $1 / 0$. Several hypotheses may be put forward to explain the decrease in EP levels observed in miners with abnormal radiographs: (1) an increase in collagen fibres interferes with the synthesis of elastin; (2) a decrease in elastin neosynthesis allows more deposition of collagen fibres; and (3) the observed association may be due to a third factor related to both elastin and collagen metabolism.

In conclusion, our results suggest that serum levels of EP may reflect some remodelling activity regarding both emphysema and fibrosis of the lung. Further epidemiological studies including various peripheral markers of lung matrix components and longitudinal design would be useful to understand the remodelling of the lung extracellular matrix. 
The authors thank all those who organised the study and participated in the collection of the data, in particular Eve Bourgkard. They also thank Daniel Hartmann for helpful discussions, and the coal miners who participated in the study.

This study was supported by ECSC grants nos 7280.03.001 and 7280.03 .035 .

1 Kucich U, Christner P, Lippmann M, Kimbel P, Williams $\mathrm{G}$, Rosenbloom J, et al. Utilization of a peroxidase antiperoxidase complex in an enzyme-linked immunosorbent assay of elastin-derived peptides in human plasma. $A m$ Rev Respir Dis 1985;131:709-13.

2 Akers S, Kucich U, Swartz M, Rosen O, Glass M, Rosenbloom J, et al. Specificity and sensitivity of the assay for elastin-derived peptides in chronic obstructive pulmonary disease. Am Rev Respir Dis 1992;145:1077-81.

3 Darnule TV, McKee M, Darnule AT, Turino GM, Mandl I. Solid-phase radioimmunoassay for estimation of elastin peptides in human sera. Anal Biochem 1982;122:302-7.

4 Schriver EE, Davidson JM, Sutcliffe MC, Swindell BB, Bernard GR. Comparison of elastin peptide concentrations in body fluids from healthy volunteers, smokers, and patients with chronic obtructive pulmonary disease. Am Rev Respir Dis 1992;145:762-6.

5 Dillon TJ, Walsh RL, Scicchitano R, Eckert B, Cleary EG, MacLennan G. Plasma elastin-derived peptide levels in normal adults, children, and emphysematous subjects. Physiologic and computed tomographic scans correlates. Physiologic and computed tomograp
Am Rev Respir Dis 1992;146:1143-8.

6 Frette C, Wei SM, Neukirch F, Sesboüé R, Martin JP, Jacob $\mathrm{MP}$, et al. Relationships of serum elastin peptide level to age, $\mathrm{FEV}_{1}$, smoking habits, alcohol consumption and PI phenotype. An epidemiological study in working men. Thorax 1992;47:937-42.

7 Frette C, Jacob MP, Defouilloy C, Atassi C, Kauffmann F, Pham QT, et al. Lack of a relationship of elastin peptide level to emphysema assessed by CT scans. Am f Respir Crit Care Med 1996;153:1544-7.

8 Caillier I, Bruant A, Mahieu B, Paris JM, Zitter M, Cervantes $\mathrm{P}$, et al. Constitution d'un échantillon de sujets à l'aide d'une étude de concordance inter-observateurs. Application à des mineurs suspects de pneumoconiose. Arch Mal Prof 1991;52:541-8.

9 Pham QT, Bourgkard E, Chau N, Willim G, Megherbi SE, Teculescu D, et al. Forced oscillation technique (FOT): a new tool for epidemiology of occupational lung diseases? Eur Respir F 1995;8:1307-13.

10 Bourgkard E, Chau N, Caillier I, Ober M, Teculescu D, Mahieu B, et al. Symptômes et fonction respiratoire des mineurs de charbon présentant des anomalies radiologiques pulmonaires. Rev Epidém Santé Publ 1994;42: 533-41

11 Quanjer $\mathrm{Ph} \mathrm{H}$. Standardised lung function testing. European Community for Coal and Steel. Bull Eur Physiopathol Respir 1983;19(Suppl 5):45-51.

12 Wei SM, Erdei J, Fülop T, Robert L, Jacob MP. Elastin peptide concentration in human serum: variation with antibodies and elastin peptides used for the enzyme-linked immunosorbent assay. F Immunol Methods 1993;164:17587 .
13 Fülop T, Wei SM, Robert L, Jacob MP. Determination of elastin peptides in normal and arteriosclerotic human sera by ELISA. Clin Physiol Biochem 1990;8:273-82.

14 Snedecor GW, Cochran WG. Statistical methods. Ames: Iowa State University Press, 1967.

15 MacLennan G, Dillon T, Walsh R, Eckert B, Drew M, Scicchitano R, et al. Correlation of plasma elastin derived peptides with pulmonary function tests. Am Rev Respir Dis 1990;141:A113.

16 Cohen AB, Girard W, McLarty J, Starcher B, Stevens M, Fair DS, et al. A controlled trial of colchicine to reduce the elastase load in the lungs of cigarette smokers with chronic obstructive pulmonary disease. Am Rev Respir Dis 1990;142:63-72.

17 Gelb AF, Schein M, Kuei J, Tashkin DP, Müller NL, Hogg JC, et al. Limited contribution of emphysema in advanced chronic obstructive pulmonary disease. Am Rev Respir Dis 1993;147:1157-61.

18 Wiesendanger $\mathrm{T}$, Teculescu $\mathrm{D}$, Brune J. Les tests à l'oxyde de carbone. Rev Mal Resp 1986;3:389-98.

19 Miller RR, Müller NL, Vedal S, Morrison NJ, Staples CA Limitations of computed tomography in the assessment of emphysema. Am Rev Respir Dis 1989;139:980-3.

20 Gevenois PA, de Maertelaer V, de Vuyst P, Zanen J, Yernault JC. Comparison of computed density and macroscopic morphometry in pulmonary emphysema. Am 7 Respir Crit Care Med 1995;152:653-7.

21 Harel S, Janoff A, Yu SY, Hurewitz A, Bergofsky EH. Desmosine radioimmunoassay for measuring elastin degradation in vivo. Am Rev Respir Dis 1980;122:769-73.

22 Pelham F, Wewers M, Crystal R, Buist AS, Janoff A. Urinary excretion of desmosine (elastin cross-links) in subjects with PiZZ alpha-1-antitrypsin deficiency, a phenotype associated with hereditary predisposition to pulmonary emphysema. Am Rev Respir Dis 1985;132:821-3.

23 Stone PJ, Gottlieb DJ, O'Connor GT, Ciccolella DE, Breuer $\mathrm{R}$, Bryan-Rhadfi J, et al. Elastin and collagen degradation products in urine of smokers with and without chronic products in urine of smokers with and without chronic 1995;151:952-9.

24 Pai V, Guz A, Philipps GJ, Cooke NT, Hutchison DCS, Tetley TD. Urinary desmosine, elastolysis, and lung disTetley TD. Urinary desmosine,

25 Collins HPR, Dick JA, Bennett JG, Pern PO, Rickards MA Thomas DJ, et al. Irregularly shaped small shadows on chest radiographs, dust exposure, and lung function in coalworkers' pneumoconiosis. Br f Ind Med 1988;45. $43-55$.

26 Mercer RR, Crapo JD. Spatial distribution of collagen and elastin fibers in the lungs. $\mathcal{F}$ Appl Physiol 1990;69:756-65.

27 Laurent PA. Pathogénie de l'emphysème pulmonaire. Place de l'équilibre protéases/antiprotéases. Paris: Editions Techniques Encycl Med Chir, 1990:3, 8.

28 D'Armiento J, Dalal S, Okada Y, Berg RA, Chada K Collagenase expression in the lungs of transgenic mice Collagenase expression in the lungs of transgenic mice

29 Naigai A, Thurlbeck WM. Scanning electron microscopic observations of emphysema in humans. A descriptive observations of emphysema in humans.

30 Ruckley VA, Gauld SJ, Chapman JS, Davies JM. Emphysema and dust exposure in a group of coal workers. physema and dust exposure in a gro

31 Hiwatari N, Shimura S, Takishima T. Pulmonary emphysema followed by pulmonary fibrosis of undetermined cause. Respiration 1993;60:354-8. 